\title{
The Power of the Name Essex in 3Henry $\mathrm{VI}$
}

\author{
Dorothy E. Litt ${ }^{1}$
}

The relationship between Queen Elizabeth I and her favorite, the Earl of Essex, reveals a complex of names and naming. There is a textual variant in $3 H$ enry $V I$ in which the shire name Essex has been omitted. From this, it appears that the omission is the result of censorship and that the unknown play performed before the Queen on the very eve of Essex's execution was 3Henry VI.

In February 1601 (1600 Old Style), Robert Devereux, 2d Earl of Essex, planned and executed a revolt against the government of the Queen of England in the city of London. Within seventeen days the rebels were apprehended, tried, and found guilty of high treason and their leader, Essex, executed in the Tower.

On Thursday, February 5th, some followers of the earl had approached the players of Shakespeare's company, the Lord Chamberlain's Men, to give a special performance of the play Richard // the next Saturday, the day before the planned revolt. ${ }^{2}$

In this play the usurper, Henry Bolingbroke, seizes the crown from King Richard II. The printed version of the play had been censored and the scene in which the king was deposed excised (Albright, "Richard II and Essex" 688, 720; Barroll disagrees 446, 448-49). Scholars generally agree that the deposition scene was probably included in the performance of February 7th (Albright "Hayward" 712-13; Chambers 1.354; Oakeshott 72; Ure Iviii).

On Sunday, February 8th, Essex's followers rode through the streets of London crying for support from the populace. None was forthcoming. After a skirmish the authorities seized the rebels and committed them to the Tower. On Monday, the queen issued a 
proclamation thanking the citizens for their loyalty (Hughes and Larkin \#808), for she was fully aware of Essex's popularity with the people, who deemed him their great hero (DNB).

On Thursday, February 19th, Essex was tried and found guilty of high treason (Black 440-41, 445-45; Harrison 296ff). On February 24th the queen signed his death warrant (DNB). At the Tower the same day he was degraded and ejected from the Order of the Garter (Strong 173-74). That same night Elizabeth had Shakespeare's company perform a play before her at Whitehall. We have no record of what that play was (Barroll 447, Steele 122). The earl was executed the next day, February 25th.

Symbolic significance haunts the names of the queen and Essex, her favorite, throughout this tragic affair. The 1st Earl of Essex had adopted the name Bolingbroke as the Devereux style (Sharpe 59 n.35), thus establishing a link with the Lancaster dynasty, with Henry IV, and with rights of succession to the English throne (Albright, "Richard II and Essex" 695). Such Bolingbroke claims, moreover, automatically suggested Henry IV's power struggle with Richard II. Thus, when Essex's cohorts selected the play Richard II to be performed the day before the planned revolt, it was probably intended to justify, as well as to incite enthusiasm for, the next day's venture. ${ }^{3}$

The Bolingbroke-Essex parallel was bolstered by the fact that the queen had, in turn, been frequently compared with Richard II by her councilors when she would not heed their advice. The queen herself was aware of the parallel in the play the rebels had performed for them at the Globe, for in August of that year she stated: "I am Richard II." At the rebels' trial this performance was made an important issue (Albright, "Richard II and Essex" 689-90), for to the queen the name of Essex, in tandem with the names of Bolingbroke and Richard II, could only mean danger.

All of the foregoing is well known; it is introductory to calling attention to a small discovery I have come upon, a textual variant in 3Henry $\mathrm{VI}$ in the placename Essex.

We have four sources for the play's text: the 1595 quarto, the reprints in the 1600 and 1619 quartos, and in our most complete and reliable version, the 1623 Folio. In the 1595 quarto (actually 
an octavo volume but frequently named a quarto by scholars) Warwick addresses Clarence:

thou sonne Clarence shalt

In Essex, Suffolke, Norfolke, and in Kent,

Stir vp the knights and gentlemen to come with thee.

(True Tragedie, 1595 64)

Warwick is commanding a muster of forces for the battle of Coventry. The 1600 and 1619 versions are substantially the same. ${ }^{5}$ In the Folio of 1623 the placename Essex is suppressed from Warwick's lines and re-written as:

and thou Sonne Clarence

Shalt stirre vp in Suffolke, Norfolke, and in Kent,

The Knights and Gentlemen, to come with thee. (4.8.167)

Although the Folio is the most reliable text, it is necessary to recognize that the omission of the shire Essex is topographically flawed. A glance at the outline of England shows that the counties lie adjacent in the east, from north to south: Norfolk, Suffolk, Essex, and Kent; by omitting Essex a gap is left in the coastline. A muster of forces traveling from Suffolk to Kent would have to pass through Essex.

The omission of Essex is, moreover, unlike an earlier reference to the shire in Act 1 in the Folio, wherein the four-county unit is retained, with Suffolk and Norfolk transposed:

Thou art deceiv'd:

'Tis not thy Southerne power

Of Essex, Norfolke, Suffolke, nor of Kent,

Which makes thee thus presumptuous and prowd... (1.1.484)

It apparently pleased Shakespeare's ear to place Essex first and Kent last in the series, in the Folio, and at 4.8 in the quarto, making the absence of Essex in the Folio problematic. 6 
The clue lies in the context of the two Folio passages. The reference in Act 1 is innocuous; it refers to Warwick's land holdings. But the reference in Act 4 concerns stirring up the populace to revolt much as the Earl of Essex had attempted to do.

I believe that the placename Essex was excised either by the censor or by Shakespeare himself. The censor at the time of the Essex revolt was Edmund Tilney, Master of the Revels. Tilney had good reason to be alive to the political importance of a name, for he had been master when the name of Sir John Oldcastle had been altered to Falstaff under pressure from the powerful Cobham family (Fehrenbach). It was he, moreover, who had censored the play Sir Thomas More, requiring that the name Lombard replace the term stranger 'alien' in the text. The play re-enacted the III May-Day riots of 1517 against foreign workmen in London. The hostility to foreigners remained a delicate issue with foreign ambassadors despite the fact that the play depicted events early in the century. They might well have taken umbrage at a display of hostility to strangers on the stage. The Lombards, by contrast, were less of a presence in London and might seem an easier target to Tilney. Clearly, Tilney understood the importance of name-politicization in a play.

It is also possible that Shakespeare censored himself, since I believe that the nameless play which the queen watched on the eve of Essex's execution was 3Henry VI. In that hushed atmosphere when the queen's favorite was at the point of death the juxtaposition of the words stir up and Essex might well have moved the author to change the lines during rehearsal.

The play had already been licensed for previous performance but Tilney would probably have scanned the play once more at that tense time; he thus would have been the first to catch the offending reference and require the author to rewrite the passage. Tilney might well have overlooked the first reference to charge with his pen at the second one. The lines were rewritten with such grace indeed that no one in studying the text, as so many scholars have done, would detect the missing province.

I believe that Elizabeth might have chosen this play to wait out the hours before Essex's execution the next day, again due to a name, the one Essex's family had adopted, Bolingbroke. The play 


\section{Names 41.4 (December 1993)}

that the rebels had chosen to watch before their revolt had been Richard II, wherein the dynasty of Henry Bolingbroke began. Just so might Elizabeth have chosen to watch the depiction of the end of that dynasty with the death of Henry VI. Thus, in a grisly game of tit-for-tat she could exploit one play as a failed answer to the rebels' failed attempt to do so.

The great speed with which the entire episode of revolt was dispatched by the queen's government would thus have been matched by this symbolic dispatch of the Bolingbroke threat which her favorite had mustered. If I am right, then of course the excision of the name Essex would have been entirely gratuitous; the name would have been uppermost in her mind at the moment. ${ }^{8}$

This example of a revision of a Shakespeare text is only one of many which scholars have examined. It offers, however, hard evidence for accuracy of the quarto texts in support of the recent controversy ${ }^{9}$ in defense of the heretofore dubbed "bad quartos," since in this case the Folio is topographically in error. My suggestion of the evening of February 24, 1601, attempts to guess at the unknown play performed on that crucial night.

The omission of the name Essex, the shire, reflects on the power of the name of the earl, which resonates in its absence.

Radcliffe College

\section{Notes}

${ }^{1}$ This is a revised version of a paper presented at the XXVIIIth Annual Names Institute, held at Baruch College, New York, 1989.

2 For a recent summary of these events, see Barroll. There is a general consensus that the play performed was Shakespeare's Richard II (Chambers 1.354; Albright, "Richard II and Essex" 689; "Hayward" 695-96; Ure Iviii; Gildersleeve 98 n.4, Hotson 164). Some who remain skeptical are Barroll (45152); Heffner (772-73); and Schoenbaum (6-7).

3 For views of the purpose of the performance, see Hotson (164) and Schoenbaum (7), who hold it was to raise the rebels' spirits; Gildersleeve (9899), McCoy (328), and Ure (Iviii) see it as encouragement to rebellion; Barroll subjects the facts to empirical analysis (445-58); Limon sees it as having 
several meanings which were available to different members of the audience (16-17). For Essex-Bolingbroke links, see Levy (259).

${ }^{4}$ Albright suggests ("Richard II and Essex" 688, 700) that the deposition scene was originally excised from Richard II, due to Elizabeth's seeing herself as Richard. Albright discusses the importance of this at length, as well as other historical analogies during the period ("Hayward" 716-18) in response to Heffner's criticism.

5 Q 1600 (True Tragedy G2) and Q 1619 (Whole Contention 2.51) are substantially the same as $Q 1595$, with a few differences in spelling and punctuation for the passage corresponding to $F 4.8$.

6 The $F$ passage (1.1), in addition to having differences in punctuation, differs from $\mathrm{Qq}$ insofar as they give the plural, powers, whereas $\mathrm{F}$ has power; they also modernize F's prowd as proud. Qq maintains the order in the shire series: Essex, Suffolk, Norfolk, Kent (1595 9, 1600 A4, 1619 5), in the same order as their later references in the passage corresponding to $F 4.8$.

7 McMillin discusses Tilney's excision $(138,144)$. Histories of London are generally silent about the presence of Lombards in the sixteenth century, suggesting they had a negligible presence there; Wheatley tells us they were all gone from Lombard Street by 1603.

A somewhat similar case of a name appearing in $\mathrm{Qq}$ and not in $\mathrm{F}$ is noted by Cairncross (xxii), where in True Tragedy, 1595, York commands:

Edward, thou shalt to Edmund Brooke Lord Cobham, With whom the Kentishmen will willingly rise...(13)

Q 1600 is substantially the same, spelling the Christian name as Edmond (sig $\mathrm{Br}$ ); Q 1619 is the same as Q 1595 (36). F drops the Christian name entirely, to name him "my Lord Cobham" (1.2.40). As far as I have been able to tell, the historical Brooke was actually named Edward, not Edmund (Boswell-Stone 295; Wingfield-Stratford 56-57). Cairncross suggests censorship (1.2.40). Certainly the names of Brooke in the Merry Wives of Windsor (Green 113ff), and Cobham, with the Oldcastle-Falstaff name-change (Taylor) suggest political influence for censorship. Yet the name Edmund is historically incorrect, and $F$ has shed the error in $Q q$; moreover, $F$ retains the name Cobham. I hesitate to draw any conclusions on the matter except to note that the censor's first name was also Edmund.

8 The altered promptbook, the company's copy, was, I believe, adapted by the $F$ editors.

${ }^{9}$ For a current discussion of the quarto-Folio debate, see loppolo (15-18). 
304 Names 41.4 (December 1993)

\section{Works Cited}

Albright, Evelyn May. "Shakespeare's Richard II and the Essex Conspiracy." PMLA 42 (1927) 686-720.

. “Shakespeare's Richard II, Hayward's History of Henry

IV, and the Essex Conspiracy." PMLA 46 (1931) 694-719.

Barroll, Leeds. "A New History for Shakespeare and His Time." Shakespeare Quarterly 39 (1988) 441-64.

Black, J. B. The Reign of Elizabeth, 1558-1603. Oxford: Clarendon, 1959.

Boswell-Stone, W. G. Shakespeare's Holinshed: The Chronicle and the Historical Plays Compared. London: Lawrence and Bullen, 1896.

Cairncross, Andrew. "Introduction." The Third Part of King Henry VI. London: Methuen, 1964.

Chambers, E. K. William Shakespeare: A Study of Facts and Problems. 2 vols. Oxford: Clarendon, 1963.

DNB: Stephen, Leslie and Sidney Lee, eds. The Dictionary of National Biography. 22 vols. London: Oxford UP, 1963-64.

Fehrenbach, Robert J. "When Lord Cobham and Edmund Tilney 'were att odds': Oldcastle, Falstaff, and the Date of 1 Henry IV." Shakespeare Studies 18 (1986) 87-101.

Gildersleeve, Virginia Crocheron. Government Regulation of the Elizabethan Drama. New York: Columbia UP, 1908.

Green, William. Shakespeare's "Merry Wives of Windsor." Princeton: Princeton UP, 1962.

Harrison, G. B. "The Earl of Essex." Times Literary Supplement 11/20/30: 974.

. The Life and Death of Robert Devereux, Earl of Essex. New York: Holt, 1937.

Heffner, Ray. "Shakespeare, Hayward, and Essex." PMLA 45 (1930) 754-80.

Hotson, Leslie. I, William Shakespeare. New York: Oxford UP, 1938.

Hughes, Paul L. and James F. Larkin, Eds. Tudor Royal Proclamations. 3 vols. New Haven: Yale UP, 1964-59. 
Ioppolo, Grace. Revising Shakespeare. Cambridge: Harvard UP, 1991.

Levy, F. J. Tudor Historical Thought. San Marino: Huntington Library, 1967.

Limon, Jerzy. Dangerous Matter: English Drama and Politics in 1623-24. Cambridge: Cambridge UP, 1985.

McCoy, Richard C. "A Dangerous Image: 'The Earl of Essex and Elizabethan Chivalry." Journal of Medieval and Renaissance Studies 13 (1983): 313-29.

McMillin, Scott. The Elizabethan Theatre and "The Book of Sir Thomas More." Ithaca: Cornell UP, 1987.

Oakeshott, Walter. The Queen and the Poet. New York: Barnes and Noble, 1961.

Schoenbaum, S. "Richard II and the Realities of Power." Shakespeare Survey 28 (1975): 1-13.

Shakespeare, William. Mr. William Shakespeare's Comedies, Histories, and Tragedies. New Haven: Yale UP, 1955.

Sharpe, Robert Boies. The Real War of the Theaters. Boston: Modern Language Association, 1935.

Steele, Mary Susan, Plays and Masques at Court during the Reigns of Elizabeth, James and Charles. Ed. Joseph Quincy Adams, et. al. New Haven: Yale UP, 1926.

Strong, Roy. The Cult of Elizabeth. [London]: Thames and Hudson, 1977.

Taylor, Gary. "The Fortunes of Falstaff." Shakespeare Survey 38 (1985): 85-100.

True Tragedy, 1595. London: C. Praetorius, 1891.

True Tragedy of Richard, Duke of York. 1600. n.p.: Tudor Facsimile Texts, 1913.

Ure, Peter. "Introduction." King Richard II. Cambridge: Harvard UP, 1956.

Wheatley, Henry B. London Past and Present. 3 vols. Detroit: Singing Tree P, 1968.

Whole Contention. 1619. Part 2. London: C. Praetorius, 1886.

Wingfield-Stratford. Esme. The Lords of Cobham Hall. London: Cassell, 1959. 